Neves et al. (2014) - SJP,17

\title{
Organizational Citizenship Behavior in Schools: Validation of a Questionnaire
}

\author{
Paula C. Neves ${ }^{1}$; Rui Paixão ${ }^{2}$; Madalena Alarcão $^{2}$; and A. Duarte Gomes ${ }^{2}$ \\ ${ }^{1}$ Instituto Politécnico de Coimbra (Portugal) \\ ${ }^{2}$ Universidade de Coimbra (Portugal)
}

Correspondence concerning this article should be addressed to Paula Costa Neves. Escola Superior de Educação. Rua Dom João, III. Solum. 3030329. Coimbra (Portugal). Phone: +351-962985292. E-mail: pneves@esec.pt 


\begin{abstract}
The present study examines the psychometric properties (including factorial validity) of an organizational citizenship behavior (OCB) scale in a school context. A total of 321 middle and high school teachers from 59 schools in urban and rural areas of central Portugal completed the OCB scale at their schools. The confirmatory factor analysis validated a hierarchical model with four latent factors on the first level (altruism, conscientiousness, civic participation and courtesy) and a second order factor $(\mathrm{OCB})$. The revised model fit with the data, $\chi^{2} / g l=1.97 ; \mathrm{CFI}=.962 ; \mathrm{GFI}=.952$, RMSEA $=.05$. The scale CCOE-Reviewed is a valid instrument to assess teacher's perceptions of OCB in their schools, allowing investigation at the organizational level of analysis.
\end{abstract}

Keywords: organizational citizenship behavior, schools, scale, Portugal. 
The Organizational Citizenship Behavior concept (OCB), defined as "individual behavior that is discretionary, not directly or explicitly recognized by the formal reward system, and that in the aggregate promotes the effective functioning of the organization" (Organ, 1988, p.4), has been studied at an entrepreneurial level (Podsakoff, MacKenzie, Paine, \& Bachrach, 2000; Podsakoff, Whiting, Podsakoff, \& Blume, 2009) and, more recently, at an educational level (DiPaola, Tarter, \& Hoy, 2005; DiPaola \& TschannenMoran, 2001; Oplatka, 2006; Oplatka \& Stundi, 2011; Somech \& Drach-Zahavy, 2000; Yilmaz \& Taşdan, 2009).

Initially proposed by Organ (1988), the concept refers to the individual behavior and actions of an employee that objectively benefit organizational effectiveness but cannot be expected from the employee, due to not being part of their formal job description, nor fostered, due to the lack of a formal reward system for it (Organ,1990). It is positive employee behavior which strongly contributes to organizational performance and efficiency (Kidwell, Mossholder, \& Bennett, 1997; Organ, 1988, 1990; Podsakoff et al., 2000; Podsakoff et al., 2009).

Studies in this field have focused more on the identification of antecedent and consequence factors of $\mathrm{OCB}$ behavior rather than on the clarification of the nature and dimension of the construct. With regards to the antecedent factors, variables have been identified which are related to personality characteristics (Borman, Penner, Allen, \& Motowidlo, 2001), personal motivation (Dávila \& Finkelstein, 2010; Rioux \& Penner, 2001), job attitudes (Organ \& Ryan, 1995), task characteristics (Cardona, Lawrence, \& Bentler, 2004; Chiu \& Chen, 2005; Passos \& Caetano, 2000), context characteristics (Jex, Adams, Bachrach, \& Sorenson 2003), and leadership types (Podsakoff et al., 2000), among others. As regards the consequence factors, studies have shown the 
relationship between OCB and organizational performance measures, such as productivity, efficiency, cost reduction, client satisfaction and turnover (Podsakoff et al., 2009).

As of yet, there is no consensus on the dimensionality of OCB's, nor is the relationship between the construct and its dimensions clearly defined, although it is consensual that it is a multidimensional construct (Law, Wong, \& Chen, 2005). Various configurations and multiple instruments for evaluation of the OCB structural dimension have been proposed (Graham, 1991; Organ, 1990; Podsakoff \& MacKenzie, 1994; Van Dyne, Graham, \& Dienesch, 1994; Van Dyne \& LePine, 1998; Van Scotter \& Motowidlo, 1996; Williams \& Anderson, 1991). Of those proposed two main types stand out: those that associate behavior according to its nature (Organ, 1988; Podsakoff, MacKenzie, Moorman, \& Fetter, 1990) and those that associate behavior according to its objective (Skarlicki \& Lathan, 1995; Williams \& Anderson, 1991).

In the first instance, although in literature specific to the field more than 30 possible types of OCB behavior are identified (Podsakoff et al., 2000), the five dimensional structure initially proposed by Organ (1988) is the most consensual (Rego, 2002). These dimensions incorporate behavior of different natures and include: altruism (behavior with the intention of helping a specific work colleague); conscientiousness (behavior that goes beyond the minimum role requirements of the organization, e.g. break management); courtesy (behavior aimed at preventing work-related conflicts); sportsmanship (tolerance to less-than-ideal circumstances without complaining) and civic virtue (behavior indicating concern and active interest in the life of the organization).

In the second instance, Williams and Anderson (1991) present OCB as a bidimensional construct where each dimension is structured according to whom the 
behavior was directed at: 1) OCBI or behaviors that immediately benefit other specific individuals; 2) OCBO or behaviors that benefit the organization as a whole.

With regards to educational institutions, literature suggests that in schools that function in an adequate and effective fashion, the teaching staff do not restrict their activities to those strictly necessary but foster others that, not being of a compulsory nature, make a difference because they have an impact in student performance (DiPaola \& Hoy, 2005). As a matter of fact, in order to achieve their objectives, schools depend on the availability of the teachers to make significant efforts, beyond the formal requirements of their function (Bogler \& Somech, 2004; Somech \& Bogler, 2002). Studies have shown the positive consequences OCB's have had on schools, namely as regards: discipline and the fostering of a positive response from superiors, students and colleagues (Oplatka, 2009); the success of students (DiPaola \& Hoy, 2005; Oplatka, 2009); civic behavior and help of the students (Oplatka, 2009); coordination of activities between staff members and their contribution for the creations of a more pleasant workplace (Podsakoff et al., 2000); a positive relationship with the school image and a cooperative and collegial school environment (Oplatka, 2009).

Although OCB's are considered to be extra-role behaviors, the difficulty in defining what is or is not part of one's function is notorious when it comes to teaching career (DiPaola \& Neves, 2009). In educational organizations, the role of a teacher encompasses a wide spectrum of tasks and responsibilities (in and out of the classroom) and it is therefore difficult to objectively define the boundaries of the profession, depending mostly on individual representations regarding the essence of the teaching career, or in other words professionalism (Gimeno, 1995). Teaching is a field of activity with a strong emphasis on helping other individuals; therefore some aspects of OCB's 
may eventually overlap with teaching responsabilities (DiPaola \& Neves, 2009; DiPaola \& Tschannen-Moran, 2001; Jimmieson, Hannam, \& Yeo, 2010).

In any case, studies focusing on OCB in an educational context are scarce (Jimmieson et al., 2010; Oplatka \& Stundi, 2011) which makes the nature of the construct in an educational environment neither very clear nor consensually operationalized. Many of the studies have attempted to identify OCB antecedents in relation with other variables (Jimmieson et al., 2010; Somech \& Ron, 2007; Yilmaz \& Taşdan, 2009). Among the studies attempting to clarify and measure the concept in an educational environment, two tendencies stand out: one that considers OCB's as a three dimensional construct and another that presents OCB's as one dimensional. In the first instance, the three dimensions are organized according to whom the behavior is directed at (Christ, Van Dick, Wagner, \& Stellmacher, 2003; Oplatka, 2006; Somech \& DrachZahavy, 2000) and include: (1) behavior directed at the students; (2) behavior directed at colleagues; and (3) behavior directed at the organization as a whole. Based on this model, Somech and Drach-Zahavy (2000) developed the first instrument designed specifically for application in an educational environment (ERB Schools).

The one dimensional perspective (DiPaola \& Tschannen-Moran, 2001) is based on the nature of the educational institutions. A school is an organization structured to help by which the distinction between helping the student or the school is artificial, seeing that all behaviors have the same objective: helping the students in being successful. With this assumption in mind, the authors developed an unifactorial scale on OCB's for schools (OCBSS) of which the more parsimonious version (OCB-Scale, DiPaola et al., 2005) was translated into various languages and adapted for use in various countries (DiPaola \& Neves, 2009; Yilmaz \& Taşdan, 2009). 
In addition, and due to the lack of consensus regarding the construct in an educational environment, that the OCB's may have a different operationalization due to cultural differences (Farh, Zhong, \& Organ, 2004), makes even more pertinent its intercultural clarification as well as validation of the instruments used in those evaluations.

The objective of the work presented here is to contribute towards the clarification of the OCB concept in Portuguese schools, and in so doing validates an instrument of measure specifically designed to collect data regarding this subject problem area.

\section{Method}

\section{Participants}

The sample under study includes 321 teachers of basic education 2nd and 3rd cycles teaching at 59 schools in urban and rural areas of Central Portugal. The sample includes teachers who teach in 26 of the 28 discipline groups. Not represented are $3^{\text {rd }}$ cycle basic education teachers in Agricultural Science and Music. The average age of the participants is $40.3(S D=8.3)$, of which $70(21.8 \%)$ are male and $251(78.2 \%)$ female.From this sample $79,5 \%$ of the teachers have permanent work contracts and $20,2 \%$ have temporary work contracts. The average duration of employment is 14,93 years and $82,2 \%$ have more than seven years of experience in the profession.

\section{Measures}

The Organizational Citizenship Behavior Questionnaire for Schools (OCBS) (Neves, 2010) (Annex 1) is a questionnaire that is completed by the individual, with 16 items arranged in Likert type (classification of 1 to 6) ordinal scale, which registers the perception each teacher has about the OCB at his/her school and allows it, through data aggregation to be studied at an organizational level. This instrument was developed based on items from OCB-Scale (DiPaola et al., 2005) and ERB Schools (Somech \& Drach-Zahavy, 2000) and rests on the conception of OCB as a four dimensional 
construct referenced to the nature of behaviors, to note: (1) altruism, which is a component of helping peers who directly or indirectly improve their performance (items $1,2,10,14$, and 16); (2) conscientiousness, which encompasses behaviors relating to work effort, such as, for example, effective time management in order to maximize the effectiveness of tasks (items 3, 5, 11, and 13); (3) civic participation, which encompasses behaviors relating to participation in tasks with the objective of promoting organizational interests as a whole (items 7, 8, 12 and 15); courtesy, which includes behavior aimed at preventing problems by planning ahead and devising solutions for predictable changes (items 4, 6 and 9).

\section{Procedures}

The data was collected at different schools by teachers studying for post-graduation and masters degrees at the Escola Superior de Educação de Coimbra, once they had been briefed on how to uniformly administer the instrument.

Sensitivity of the items was studied taking into consideration asymmetry and kurtosis coefficients. For the reliability study Cronbach's alpha index was applied to each of the factors and, for the total scale, a standardized alpha since it was considered to be a better estimator of true reliability (Kamata, Turhan, \& Darandari, 2003). Factorial validation and the second-order $2^{\text {nd }}$ order structural hierarchy were studied using AMOS 20 software. In this analysis, the following adjustment indexes were used $\chi^{2} / g l$; Comparative Fit Index (CFI); Goodness of Fit Index (GFI), Root Mean Square Error of Approximation ( RMSEA). The quality of the modified models and of the second- order factor structure was also evaluated and compared using Akaike Information Criterion(AIC),Bays Information Criterion (BIC) and Browne-Cudeck criterion (BCC information criteria. The criterion used were: $\chi^{2} / g l$ between 1 and 2 ; CFI 
and GFI greater than .9 RMSEA lower than .5: it was assumed in the information criteria lower values indicated a better adjustment to the model (Byrne, 2010).

\section{Results}

Temporal stability

Temporal stability was assessed by means of retesting of a sub-sample of 187 teachers within 3 weeks of the first test. The data showed the following correlations between dimensions: Altruism $.62(p<.01)$; Conscientiousness $68(p<.01)$; Civic Participation $.58(p<.01)$; Courtesy $.57(p<.01)$ and $.69(p<.01)$ on the global scale score, by which the temporal stability is considered to be acceptable (Robinson, Shaver, \& Wrightsman, 1991).

\section{Sensitivity}

The sensitivity of the 16 items was evaluated using asymmetry and kurtosis coefficients and respective critical ratios (Table 1). Asymmetry and kurtosis coefficients with absolute values greater than 1 were not identified, therefore, it is considered that there are no sensitivity or significant deviations from normal (Maroco, 2003). Because all manifest variables presents asymmetry and kurtosis near zero the assumption of multivariate normality is plausible (Maroco, 2010).

\section{$<$ Table 1>}

\section{Factorial validity}

The factorial validity of the instrument was tested on four models: model 1 (unifactorial), model 2 (four first-order factors), model 3 (four modified first-order factors) and model 4 (four modified first-order factors with 1 second-order factor). The sample size and plausibility of the normality justify the use of the estimate method of maximum likelihood (ML) because its produces results that are more efficient and 
consistent and is more robust to violation of the assumption of normality if the asymmetry and flattening of the manifest variables are not too large (Maroco, 2010).

The confirmatory factor analysis of model 1 showed adjusted fit indexes of poor or unacceptable factorial validity indicating the existence of more than one factor (Table 2).

The confirmatory factor analysis of the second model (four first-order factors) showed questionable adjustment of fit indexes (Table 2), although the standardized factor values of all the items are greater than .5 . The reliability of the first-order factors was assessed using Cronbach's alpha internal consistency coefficient and present the following values: altruism .83; conscientiousness.77; civic participation.75; courtesy.76. The total scale presents a standardized alpha of.90.

\section{<Table 2>}

The identification of a questionable factorial validity value justified the adjustment of the original model in accordance with the modification indices supplied by the program. In the third model (four modified first-order factors), items 10 and 16 relating to altruism, item 5 relating to conscientiousness and item 12 relating to civic participation, were removed. because the modification indices suggested the saturation of these items on factors other than those suggested initially. The final modified scale presents the same four factors but with three items in each one. The adjustment of fit indexes for model 3 range between good and very good (Table 2). The factors are all positively correlated: altruism is positively correlated with conscientiousness $(r=.85 ; p<.001)$, with civic participation $(r=$ $.69 ; p<.001)$ and with courtesy $(r=.78 ; p<.001)$; conscientiousness correlates with civic participation $(r=.68 ; p<.001)$ and with courtesy $(r=.66 ; p<.001)$; and finally, civic participation correlates with courtesy $(r=.60 ; p<.001)$. 
The theoretical framework considered (Organ, 1988) and the high correlation between factors pointed to the existence of a second-order factor, by which the hypothesis was tested. For this new model (model 4: four modified first-order factors with 1 second-order factor), organized hierarchically, the OCB's are depicted as a second-order factor (Figure 1) with adjustment of fit indexes ranging between good and very good (Table 2) indicating a high factorial validity for this revised scale.

\section{$<$ Figure 1>}

In this hierarchical model the second-order factors altruism, conscientiousness, civic participation and courtesy (each with three items) present alpha values of.73;.71,.70 and.76 respectively. The global scale presents a standardized alpha of .87 .

In comparison with the OCBS proposed in the second model tested this new structure, which we will call Escala de Comportamentos de Cidadania Organizacional em Escolas Revista (Organizational Citizenship Behavior Scale in Schools - Revised) (Figure 1), presents a significantly better and parsimonious adjustment $\left[\Delta \chi^{2}(48)=169.5 ; p<.001\right]$ since the AIC, BIC and BCC criteria present lower values in the revised scale with secondorder factors than in the original scale $(\triangle \mathrm{AIC}=190 ; \Delta \mathrm{BIC}=227.2 ; \Delta \mathrm{BCC}=191.4)$.

Thus, the OCB's can be considered a second-order factor with estimated numerical indexes based on the factorial scores. The standardized values of the OCB levels are calculated based on the following expression (1)

$\mathrm{OCB}=.037 \mathrm{It}_{9}+.05 \mathrm{It}_{6}+.075 \mathrm{It}_{4}+.021 \mathrm{It}_{15}+.047 \mathrm{It}_{8}+.082 \mathrm{It}_{7}+.112 \mathrm{It}_{13}+.098 \mathrm{It}_{11}+.054 \mathrm{It}_{3}+$ $.138 \mathrm{It}_{14}+.116 \mathrm{It}_{2}+.098 \mathrm{It}_{1}$.

The scores for the four sub-scales are obtained by expressions (2), (3), (4) and (5) :

$$
\begin{aligned}
& \text { Altruism }=130 \mathrm{It}_{1}+.153 \mathrm{It}_{2}+.182 . \mathrm{It}_{14} \\
& \text { Conscientiousness }=.96 \mathrm{It}_{3}+.173 \mathrm{It}_{11}+.198 \mathrm{It}_{13}
\end{aligned}
$$


Civic Participation $=.358 \mathrm{It}_{7}+.206 \mathrm{It}_{8}+.09 \mathrm{It}_{15}$

Courtesy $=.326 \mathrm{It}_{4}+.218 \mathrm{It}_{6}+.162 \mathrm{It}_{9}$

\section{$<\mathrm{H} 1>$ Discussion}

The nature of the OCB construct and the instruments used to study it in an educational environment are not, yet, consensual and this may be related with its low level of study (Jimmieson et al., 2010). In this article we studied OCBS characteristics on the Portuguese teacher population and propose an instrument of measure to evaluate the perceptions of teachers regarding the application of OCB in schools.

The four factor structure, introduced in the initial version of the instrument (Neves, 2010), held up and was expanded to a second-order hierarchical structure, which fitted the data better.

The multi-factorial four factor structure fits the taxonomy subgroup that organize the OCB's based on the nature of behavior and identifies itself more closely with Organ's initial proposal (1988) for the business environment. The global similarity between the two structures shows that, although the teaching profession has specific characteristics, what may be described as extra-role behavior may be of an equivalent nature to any other profession. In other words, "activities that support the social and psychological environment in which task performance takes place" (Organ, 1997, p.95) may be carried out by teachers using behavior that, although specific to the teaching profession, are equivalent, in their nature, to those of any other profession.

For any scale of measure all the items should measure the same construct, with a determined margin of error. In a multi-dimensional construct, the dimensions represent their different materializations in which case the construct is defined by the amount of correlated variance shared by the dimensions (latent non-observable variables), underlying a set of observable indicators (Jarvis, MacKenzie, \& Podsakoff, 2003, 
2012). The model presented shows the OCB conception as a latent construct with four factors (altruism, conscientiousness, civic participation and courtesy), resulting from different forms of expression of the same construct. In this manner, it can be assumed that we stand before a set of $1^{\text {st }}$ level latent factors (dimensions), with observable indicators (variables / items) which, in turn, are themselves the observable indicators for the underlying second level construct (OCB). Although the construct may also be viewed as an aggregate model (Law et al., 2005), the conceptualization of the OCB as a latent model is the most used, establishing itself as a good way to conceptualize and describe the relations between the dimensions of the OCB construct.

Finally, the OCBS-R presents itself as an instrument that allows for the collection of information directly at teacher level, not at their superior's level, regarding their perception of OCB application in the schools where they work. Since it does not collect specific teacher information, it allows a valid index to be obtained that expresses the shared perceptions of the teachers regarding the levels of OCB of schools, making possible studies at an organizational level. 


\section{References}

Bogler, R., \& Somech, A. (2004). Influence of teacher empowerment on teachers'organizational commitment,professional commitment and organizational citizenship behavior. Teaching and Teacher Education, 20, 277289. http://dx.doi.org/10.1016/j.tate.2004.02.003

Borman, W. C., Penner, L. A., Allen, T. D., \& Motowidlo, S. J. (2001). Personality predictors of citizenship performance. International Journal of Selection and Assessment, 9, 52-69. http://dx.doi.org/10.1111/1468-2389.00163

Byrne, B. M. (2010). Structural equation modeling with AMOS: Basic concepts, applications, and programming. New York, NY: Routledge.

Cardona, P., Lawrence, B. S., \& Bentler, P. M. (2004). The influence of social and work exchange relationships on organizational citizenship behavior. Group \& Organization Management, 29, 219-247. http://dx.doi.org/10.1177/1059601103257401

Chiu, S.-F., \& Chen, H.-L. (2005). Relationship between job characteristics and organizational citizenship behavior: The meditational role of job satisfaction. Social Behavior and Personality, 33, 523-539.

Christ, O., Van Dick, R., Wagner, U., \& Stellmacher, J. (2003). When teachers go the extra mile: Foci of organisational identification as determinants of different forms of organisational citizenship behavior among schoolteachers. British Journal of Educational Psychology, 73, 329-341 . http://dx.doi.org/10.1348/000709903322275867

Dávila, M. C., \& Finkelstein, M. A. (2010). Predicting organizational citizenship behavior from the funcional analysis and role identidy perspectives:Further 
evidence in spanish employees. The Spanish Journal of Psychology, 13, 277283.

DiPaola, M. F., \& Hoy, W. K. (2005a). School characteristics that foster organizational citizenship behavior. Journal of School Leadership, 15, 387-406.

DiPaola, M. F., \& Neves, P. C. (2009). Organizacional citizenship behaviors in American and Portuguese public schools: Measuring the construct across cultures. Journal of Educational Administration, 47, 490-507. http://dx.doi.org/10.1108/09578230910967464

DiPaola, M. F., \& Tschannen-Moran, M. (2001). Organizational citizenship behavior in schools and its relationship to school climate. Journal of School Leadership, 11, 424-447.

DiPaola, M. F., Tarter, C. J., \& Hoy, W. K. (2005). Measuring organizational citizenship of schools: The OCB scale. In W. K. Hoy, \& M. C. G. (Edits.), Educational Leadership and Reform (Vol. 4, pp. 319-341). Greenwich, CT: Information Age Publishing.

Farh, J.-L., Zhong, C.-B., \& Organ, D. W. (2004). Organizational citizenship behavior in the people's Republic of China. Organization Science, 15, 241-253. http://dx.doi.org/10.1287/arsc.1030.0051

Gimeno, J. (1995). Consciência e acção sobre a prática como libertação profissional. [Awareness and action on professional practice as professional liberation] In A. Nóvoa, Profissão professor [Teaching profession] (2 ${ }^{\mathrm{a}}$ Ed., pp. 63-92). Porto, Portugal: Porto Editora.

Graham, J. W. (1991). An essay on organizational citizenship behavior . Employee Responsibilities and Rights Journal , 4, 249-270. http://dx.doi.org/10.1007/BF01385031 
Jarvis, C. B., MacKenzie, S. B., \& Podsakoff, P. M. (2003). Critical review of construct indicators and measurement model misspecification in marketing and consumer research. Journal of Consumer Research, 30, 199-218.

http://dx.doi.org/10.1086/376806

Jarvis, C. B., MacKenzie, S. B., Podsakoff, \& P. M. (2012). The negative consequences of measurement model misspecification: A response to Aguirre-Urreta and Marakas. Mis Quarterly, 36, 139-146.

Jex, S. M., Adams, G. A., Bachrach, D. G., \& Sorenson, S. (2003). The impact of situational constraints, role stressors, and commitment on employee altruism. Journal of Occupational Health Psychology, 8, 171-180. http://dx.doi.org/10.1037/1076-8998.8.3.171

<REFJ>Jimmieson, L., N., Hannam, R. L., \& Yeo, G. B. (2010). Teacher organizational citizenship behaviors and job efficacy: Implications for students quality of school life. British Journal of Psychology, 101, 453-479. http://dx.doi.org/10.1348/000712609X470572

$<$ REFJ $>$ Kamata, A., Turhan, A., \& Darandari, E. (2003). Estimating reliability for multidimensional composite scale scores. Annual meeting of American Educational Research Association. Florida State University Retrieved from $\underline{\text { http://mailer.fsu.edu/ akamata/papers/MD_rel_paper.pdf }}$

Kidwell Jr, R. E., Mossholder, K. W., \& Bennett, N. (1997). Cohesiveness and organizational citizenship behavior: A multilevel analysis using work groups and individuals . Journal of Management, 23, 775-793. http://dx.doi.org/10.1016/S0149-2063(97)90029-5

Law, K. S., Wong, C.-S., \& Chen, Z. X. (2005). The construct of organizational citizenship behavior: Should we analyze after we have conceptualized. In D. L. 
Turnipseed (Ed.), Handbook of organizational citizenship behavior (pp. 47-65).

New York, NY: Nova Science Publishers, Inc.

Maroco, J. (2003). Análise estatística com utilização do spss [Statistical analysis using spss] (2 ${ }^{\mathrm{a}}$ Ed.). Lisboa, Portugal: Edições Sílabo.

Maroco, J. (2010). Análise de Equações Estruturais [Structural Equation Analysis]. Pero Pinheiro, Portugal: Reportnumber.

Neves, P. C. (2010). Comportamentos de cidadania organizacional em escolas do ensino secundário. Tese de doutoramento não publicada [Organizational citizenship behaviors in secondary schools. Unpublished doctoral thesis]. Universidade de Coimbra. Coimbra, Portugal.

Oplatka, I. (2006). Going beyond role expectations: Toward an understanding of the determinats and components of teacher organizational citizenship behavior. Educational Administration Quarterly, 42, 385-423. http://dx.doi.org/10.1177/0013161X05285987

Oplatka, I. (2009). Organizational citizenship behavior in teaching: The consequences for teachers, pupils and the school. International Journal of Educational management, 23, 375-389. http://dx.doi.org/10.1108/09513540910970476

Oplatka, I., \& Stundi, M. (2011). The components and determinants of preschool teacher organizacional citizenship behavior. International Journal of Educational Management, 25, 223-236. http://dx.doi.org/10.1108/09513541111120079

Organ, D. W. (1988). Organizational citizenship behavior: The good soldier syndrome. Lexington MA: Lexington Books.

Organ, D. W. (1990). The motivational basis of organizational citizenship behavior. In B. M. Staw, \& L. Cummings (Edits.), Research in Organizational Behavior (Vol. 12, pp. 43-72). Greenwich, CT: JAI Press. 
Organ, D. W. (1997). Organizational citizenship behavior: It's construct clean-up time. Human Performance, 10, 85-97. http://dx.doi.org/10.1207/s15327043hup1002_2

Organ, D. W., \& Ryan, K. (1995). A meta-analytic review of attitudinal and dispositional predictors of organizational citizenship behavior. Personnel Psychology, 48, 775-802. http://dx.doi.org/10.1111/j.1744-6570.1995.tb01781.x

Passos, A., \& Caetano, A. (2000). Comportamento de cidadania organizacional: Factores determinantes [Organizational citizenship behavior: Determinants factors]. Psychologica, 23, 71-93.

Podsakoff, N. P., Whiting, S. W., Podsakoff, P. M., \& Blume, B. D. (2009). Individualand organizational-level consequences of organizational citizenship behaviors: A meta-analysis. Journal of Applied Psychology, 94, 122-141. http://dx.doi.org/10.1037/a0013079

Podsakoff, P. M., \& MacKenzie, S. B. (1994). Organizational citizenship behaviors and sales unit effectiveness. Journal of Marketing Research, 31, 351-363.

Podsakoff, P. M., MacKenzie, S. B., Moorman, R. H., \& Fetter, R. (1990). Transformational leader behaviors and their effects on followers' trust in leader, satisfaction, and organizational citizenship behaviors. The Leadership Quarterly, 1, 107-142. http://dx.doi.org/10.1016/1048-9843(90)90009-7

Podsakoff, P. M., MacKenzie, S. B., Paine, J. B., \& Bachrach, D. G. (2000). Organizational citizenship behaviors: A critical review of the theoretical and empirical literature and suggestions for future research. Journal of Management, 26, 513-563. http://dx.doi.org/10.1016/S0149-2063(00)00047-7

Rego, A. (2002). Comportamentos de cidadania nas organizações [Citizenship behavior in organizations]. Lisboa, Portugal: McGraw-Hill. 
Rioux, S. M., \& Penner, L. A. (2001). The causes of organizational citizenship behavior: A motivational analysis. Journal of Applied Psychology, 86, 13061314. http://dx.doi.org/10.1037//0021-9010.86.6.1306

Robinson, J., Shaver, P., \& Wrightsman, L. S. (1991). Measures of personality and social pshychological attitudes. San Diego, CA: Academic Press.

Skarlicki, D., \& Lathan, G. (1995). Organizational citizenship behavior and performance in a university setting. Canadian Journal of Administrative Sciences, 12, 175-181. http://dx.doi.org/10.1111/j.1936-4490.1995.tb00082.x

Somech, A., \& Bogler, R. (2002). Antecedents and consequences of teacher organizational and professional commitment. Educational Administration Quarterly, 38, 555-577. http://dx.doi.org/10.1177/001316102237672

Somech, A., \& Drach-Zahavy, A. (2000). Understanding extra-role behavior in schools: The relationships between job satisfaction, sense of efficacy, and teachers' extrarole behavior. Teaching and Teacher Education, 16, 649-659. http://dx.doi.org/10.1016/S0742-051X(00)00012-3

Somech, A., \& Ron, I. (2007). Promoting organizational citizenship behavior in schools: The impact of individual and organizational characteristics.

Educational Administration Quarterly, 43, 38-66. http://dx.doi.org/10.1177/0013161X06291254

Van Dyne, L., \& LePine, J. A. (1998). Helping and voice extra-role behaviors: Evidence of construct and predictive validity. Academy of Management Journal, 41, 108-119. http://dx.doi.org/10.2307/256902

Van Dyne, L., Graham, J. W., \& Dienesch, R. M. (1994). Organizacional citizenship behavior: Construct redefinition, measurement, and validation. Academy of Management Journal, 37, 765-802. 
Van Scotter, J. R., \& Motowidlo, S. J. (1996). Interpersonal facilitation and job dedication as separate facets of contextual performance. Journal of Applied Psychology, 81, 525-531. http://dx.doi.org/10.1037//0021-9010.81.5.525

Williams, L. J., \& Anderson, S. E. (1991). Job satisfaction and organizational commitment as predictors of organizational citizenship and in-role behaviors. Journal of Management, 17, 601-617. http://dx.doi.org/10.1177/014920639101700305

Yilmaz, K., \& Taşdan, M. (2009). Organizational citizenship and organizational justice in Turkish primary schools. Journal of Educational Administration, 47, 108126. http://dx.doi.org/10.1108/09578230910928106 
Table 1.

Sensitivity of the 16 OCBS item

\begin{tabular}{|c|c|c|c|c|c|c|c|}
\hline Item & Median & Mean & Asymmetry & Critical ratio & Kurtosis & Critical ratio & Range \\
\hline 1 & 4 & 3.93 & $-0,39$ & $-2,85$ & $-0,55$ & $-2,01$ & $1-6$ \\
\hline 2 & 3 & 3.18 & 0,13 & 0,98 & $-0,11$ & $-0,40$ & $1-6$ \\
\hline 3 & 5 & 4.42 & $-0,55$ & $-4,04$ & $-0,55$ & $-2,01$ & $2-6$ \\
\hline 4 & 3 & 3.13 & 0,25 & 1,82 & $-0,76$ & $-2,80$ & $1-6$ \\
\hline 5 & 5 & 4.46 & $-0,57$ & $-4,22$ & 0,09 & 0,32 & $1-6$ \\
\hline 6 & 4 & 3.68 & $-0,08$ & $-0,62$ & $-0,78$ & $-2,88$ & $1-6$ \\
\hline 7 & 4 & 3.97 & $-0,32$ & $-2,38$ & $-0,41$ & $-1,49$ & $1-6$ \\
\hline 8 & 3 & 3.51 & 0,03 & 0,19 & $-0,68$ & $-2,49$ & $1-6$ \\
\hline 9 & 3 & 3.20 & 0,25 & 1,85 & $-0,77$ & $-2,84$ & $1-6$ \\
\hline 10 & 3 & 3.15 & 0,25 & 1,85 & $-0,48$ & $-1,77$ & $1-6$ \\
\hline 11 & 4 & 4.29 & $-0,34$ & $-2,46$ & $-0,41$ & $-1,51$ & $1-6$ \\
\hline 12 & 3 & 3.38 & $-0,04$ & $-0,32$ & $-0,51$ & $-1,90$ & $1-6$ \\
\hline 13 & 5 & 4.57 & $-0,44$ & $-3,24$ & $-0,15$ & $-0,56$ & $1-6$ \\
\hline 14 & 4 & 3.99 & $-0,43$ & $-3,17$ & $-0,43$ & $-1,59$ & $1-6$ \\
\hline 15 & 3 & 2.81 & 0,56 & 4,15 & $-0,29$ & $-1,06$ & $1-6$ \\
\hline 16 & 4 & 4.21 & $-0,34$ & $-2,53$ & $-0,51$ & $-1,88$ & $1-6$ \\
\hline
\end{tabular}


Table 2.

Adjustment indexes for each proposed model

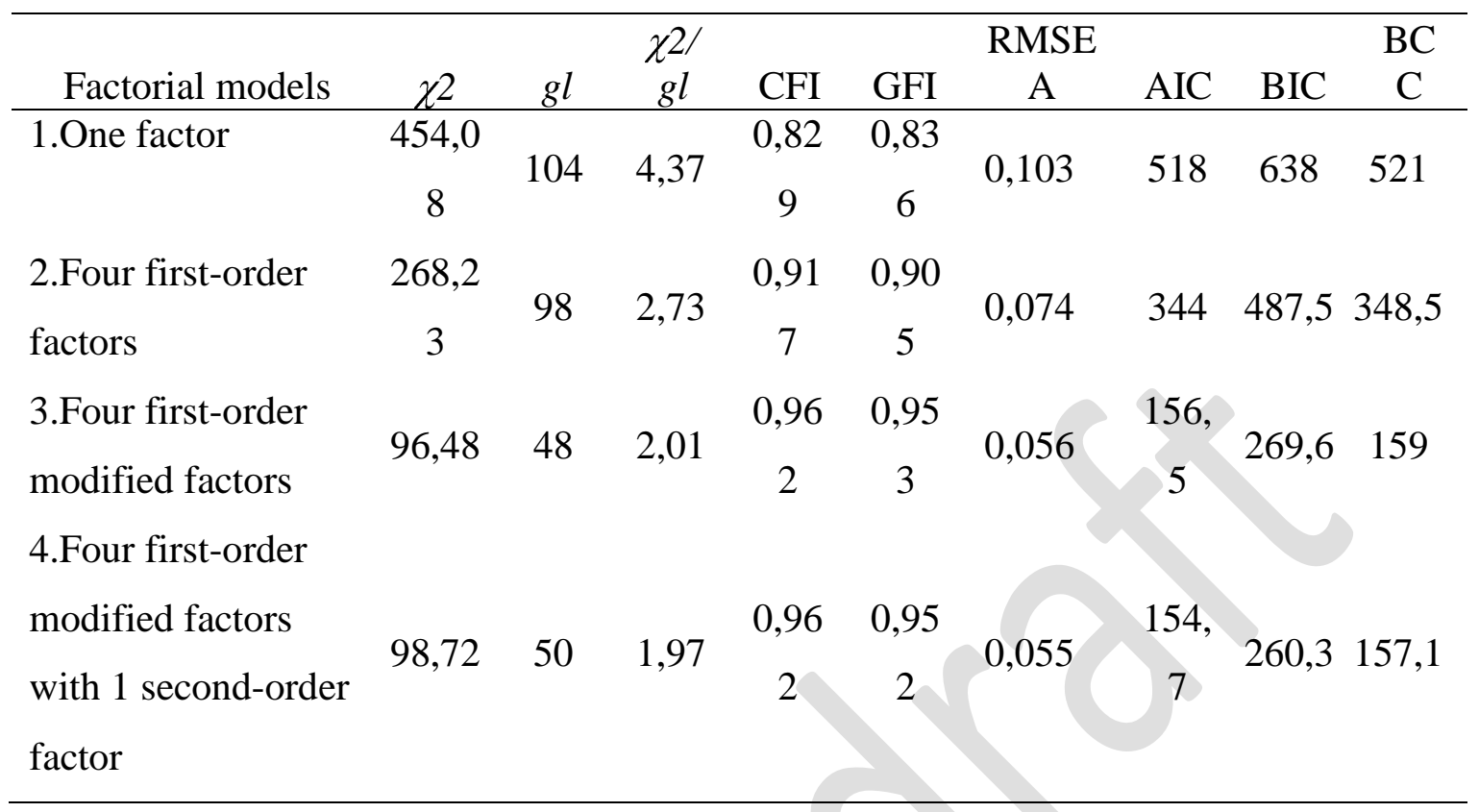




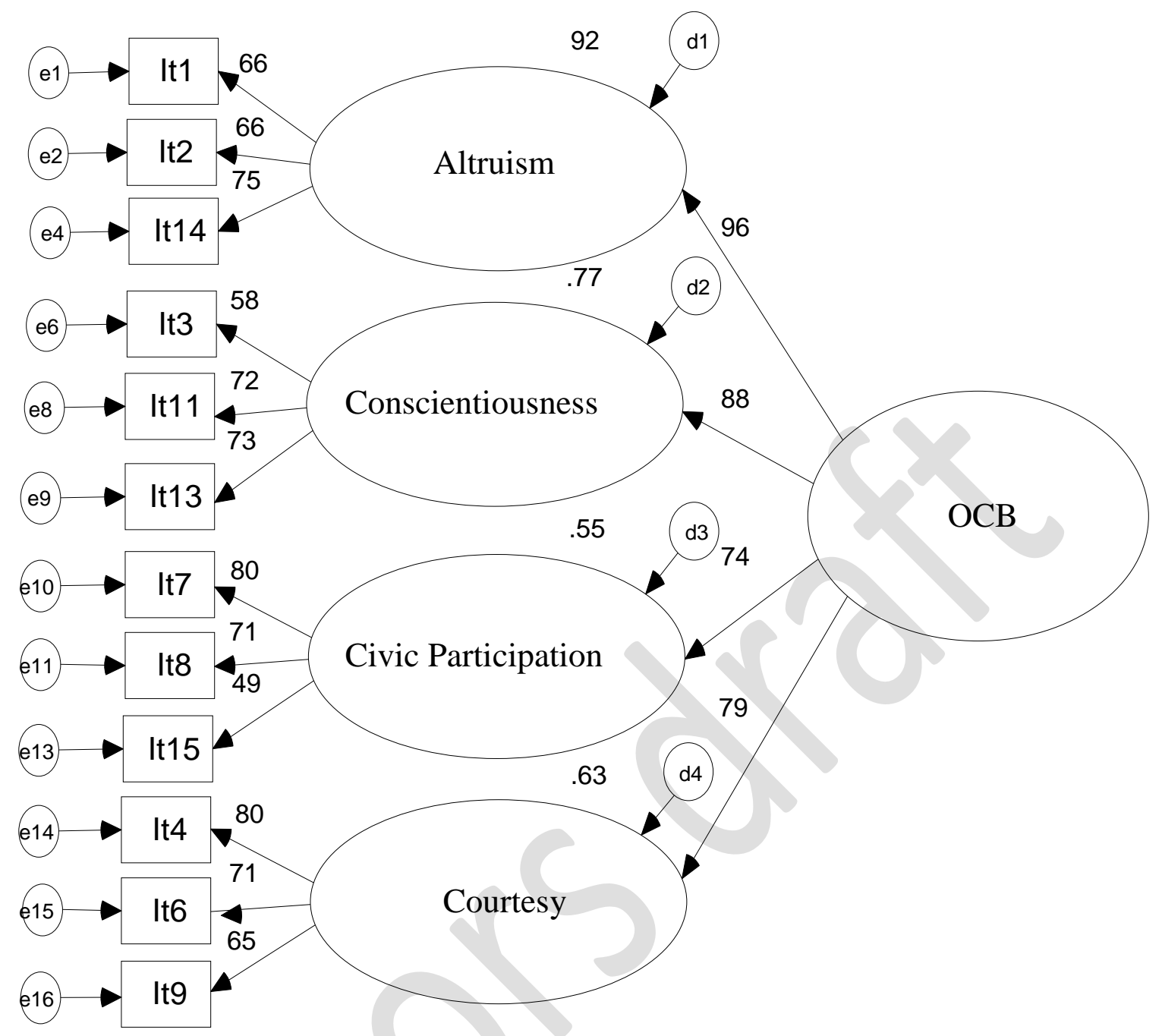

Figure 1. Four modified first-order factors with one second-order factor, including the standard factor influences for each of the items and $\mathrm{R}^{2}$ values for each of the first-order factors. 


\section{Appendix 1}

Items of the Organizational Citizenship Behavior Questionnaire in Schools OCBS (Neves, 2010)

Instructions for filling in: Indicate to what extent you disagree or agree with the following statements about your current school.

1. Os professores ajudam voluntariamente os novos professores

2. Os professores oferecem-se para integrar novos grupos de trabalho

3. Os professores chegam pontualmente ao trabalho e às reuniões

4. Quando necessitam de ser substituídos (faltas, atestado...) os professores tomam a iniciativa de se apresentarem aos professores substitutos e de os ajudarem

5. Os professores iniciam prontamente os trabalhos e fazem uma utilização eficaz do tempo de aulas

6. Os professores avisam com antecedência os colegas sobre alterações de horário ou calendário (faltas...)

7. Os professores apresentam sugestões inovadoras para melhorar a qualidade global da escola

8. Os professores organizam atividades sociais para a escola

9. Os professores preparam os materiais a utilizar pelos professores que os vão substituir

10. Os professores ajudam os colegas que estão mais sobrecarregados

11. Os professores participam ativamente nas reuniões

12. Os professores oferecem-se para desempenhar papéis e tarefas não obrigatórias

13. Os professores esforçam-se por adquirir novas competências em matérias que contribuem para o seu trabalho

14. Os professores oferecem aos seus colegas materiais que prepararam para as suas aulas

15. Os professores apoiam a direção nos seus tempos livres

16. Os professores trabalham em colaboração com os colegas (planificação 